\title{
MICROBIOLOGICAL STUDIES OF COCKROACHES FROM THREE LOCALITIES IN GABORONE, BOTSWANA
}

Sisai Mpuchane ${ }^{*}$, Ignatius M. Matsheka ${ }^{1}$, Berhanu A. Gashe ${ }^{1}$, Joseph Allotey ${ }^{1}$, Gervus Murindamombe and Neema Mremal.

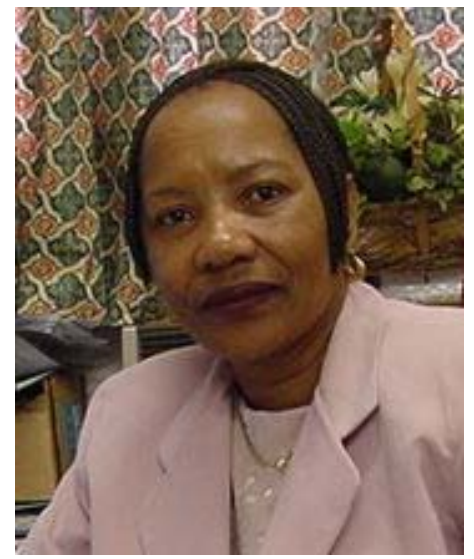

Sisai Mpuchane

* Corresponding author - Email: mpuchans@mopipi.ub.bw

${ }^{1}$ University of Botswana, Department of Biological Sciences, Pr. Bag UB00704

Gaborone, Botswana. Fax: 267-3185097; Tel.: 267-3552598.

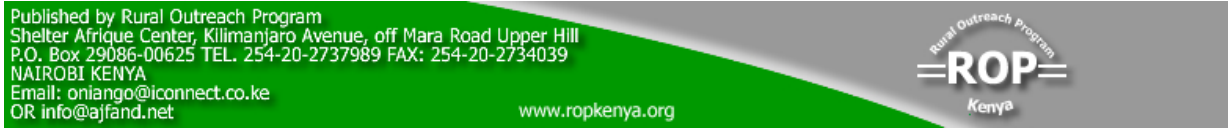




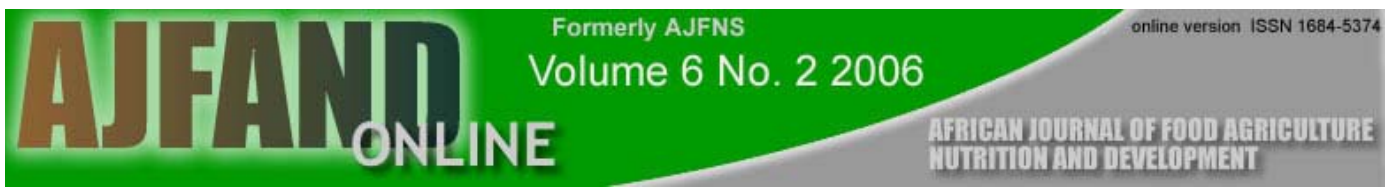

ABSTRACT

Cockroaches have become the most common pests in a majority of households in Gaborone, the capital city of Botswana Their presence has always raised safety concerns, especially as carriers of food-borne pathogens and food-spoilage organisms. To address the safety issues, bacteriological investigations were carried out on cockroaches trapped from the kitchens and toilets of three localities in Gaborone, households in Botswana. The bacterial, total spore forming, Bacillus cereus, coliforms and $E$. coli counts from the surfaces of cockroaches were estimated using bacteriological media. Aerobic and facultatively anaerobic bacteria from the fecal pellets were isolated and characterized. Specialized media were used for culturing pathogens. $67 \%, 22.2 \%$ and $28.6 \%$ of the cockroaches trapped in the kitchen from Central/Broadhurst, Old Naledi and Tlokweng, respectively, had aerobic plate counts of $\geq 10^{6} \mathrm{CFU} /$ cockroach. The cockroaches trapped from the toilets had higher counts than kitchens. Sporeformers were present in most samples though in lower numbers. However, Bacillus cereus was only found in some of the cockroaches at much lower numbers. As much as 70$98.3 \%$ of the cockroaches had coliforms; but, $E$. coli was only found in 5-6.5\% of the cockroaches at $\geq 10^{3} \mathrm{CFU} /$ cockroach. 70 species of bacteria representing 37 genera were isolated from the surface and fecal pellets. Even though the majority of the bacteria that were isolated from the surfaces were Gram negative those from the pellets were mostly Gram positive. The most common and abundant species belonged to Pseudomonas and Serratia, with members of the Enterobacteriaceae following. In the pellets, species of Bacillus were predominant, but, there were some members of Enterobacteriaceae. Pathogens like Salmonella, Shigella and B. cereus were isolated. Opportunistic pathogens like species of Pseudomonas, Klebsiella and Vibrio and food spoilage bacteria such as species of Enterobacter, Citrobacter, Escherichia, Erwinia, and Pseudomonas were also found. Proper care in disposal of food remnants and overall cleanliness at the households prevents cockroaches from foraging in the kitchen and toilet.

Key words: micro-organisms, cockroaches, antibiotic resistance, households 


\title{
ÉTUDES MICROBIOLOGIQUES DES CANCRELATS DANS TROIS RÉGIONS DE GABORONE, BOTSWANA
}

\author{
RÉSUMÉ
}

Les cancrelats sont devenus les insectes nuisibles les plus communs dans la majorité des ménages à Gaborone, capitale du Botswana. Leur présence a toujours soulevé des préoccupations de salubrité, surtout comme vecteurs des pathogènes portés par la nourriture et des organismes de décomposition de la nourriture. Afin de traiter les problèmes d'hygiène, des études bactériologiques ont été menées sur les cancrelats pris au piège dans les cuisines et les toilettes des ménages de trois régions de Gaborone au Botswana. Les quantités du Bacillus cereus bactérien et mousseux, des coliformes et du $E$. coli sur les surfaces de cancrelats ont été estimées grâce à l'utilisation de moyens bactériologiques. Les bactéries aérobies et les bactéries éventuellement anaérobiques provenant des boulettes fécales ont été isolées et ensuite définies. Des moyens spécialisés ont été utilisés dans la culture des pathogènes : $67 \%, 22,2 \%$ et $28,6 \%$ des cancrelats pris au piège dans les cuisines de Central/Broadhurst, Old Naledi et Tlokweng avaient un dénombrement de plaques aérobics de $>106$ CFU/CANCRELAT. Les cancrelats pris au piège dans les toilettes avaient un plus grand nombre que ceux captés dans les cuisines. Des substances mousseuses étaient présentes dans la plupart des échantillons bien qu'en quantités plus faibles. Cependant, Bacukkys cereus a été seulement décelé dans certains des cancrelats en plus faible quantité. $\mathbf{7 0 - 9 8 , 8 \%}$ des cancrelats avaient des coliformes ; mais le $E$. coli a été seulement trouvé dans les cancrelats $\geq 10^{3}$ CFU/CANCRELAT. Soixante-dix espèces de bactéries représentant 37 genera ont été isolées sur la surface et dans les boulettes fécales. Bien que la majorité des bactéries qui ont été isolées des surfaces soient Gram négatif, celles cueillies des boulettes étaient surtout Gram positif. L'espèce la plus fréquente et abondante appartient au Pseudomonas et Dentelures, suivie des membres du Enterobacteriaceae. Dans les boulettes, l'espèce de Bacillus était prédominante, mais il y avait quelques membres du type Enterobacteriaceae. Les pathogènes tels que Salmonella, Shigella et $B$. cereas ont été isolés. Les pathogènes opportunistes tels que les espèces de Pseudomonas, Klebsiella et Vibrio et les bactéries des déchets de nourriture telles que les espèces Enterobacter, Citrobacter, Escherichia, Erwinia, et Pseudomonas ont également été identifiés. Une attention particulière devra être prêtée à la disposition des restes alimentaires ainsi qu'à la propreté générale des ménages afin de prévenir la fouille des cancrelats dans les cuisines et toilettes.

Mots clés : micro-organismes, cancrelats, résistance antibiotique, ménages. 


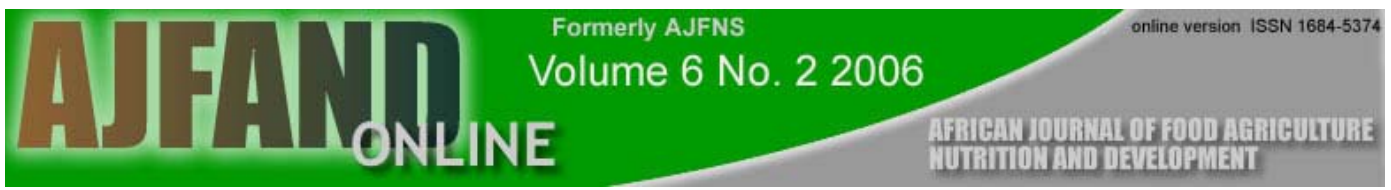

\section{INTRODUCTION}

German cockroaches (Blattella germanica) have become a significant domestic pest that are not only repugnant because of their association with dirt, but because of their possible health risks in spreading diseases, causing allergies, tainting food odours and contaminating food and food processing environments.

Increased infestation of the German cockroach in buildings has increased with urbanization [1]. Poor management of urban refuse has been linked with the increase in the population of cockroaches in urban areas [2]. In Botswana, cockroaches have even flourished in the streets where foods are vended. They now make up as much as 81-91 $\%$ of insects trapped around vending sites, followed by Crematogaster (3\%), the green bottle $(2 \%)$ and then the housefly $(2 \%)$ [3].

German cockroaches have also been isolated from various environments including hospitals, food industries and landfill sites [4]. They are also common pests in bakeries, food processing facilities and kitchens $[5,6]$. While the causal relationship between cockroaches and disease still needs to be established, they also pose danger in the dairy industry since they carry microorganisms including Salmonella, Pseudomanads, E. coli, Listeria monocytogenes, and conidia of mycotoxigenic fungi [7, 8, 9]. A survey of students', teachers' and low-income employees' residences revealed average total counts of $1.35 \times 10^{8}, 5.99 \times 10^{7}$ and $1.64 \times 10^{8}$ respectively [8]. In another study, $98.5 \%$ of cockroaches from hospitals and residences were carriers of microorganisms and involved in the aetiology of nosocomial infections $[10,11,12]$.

At the household level, a relationship has been established between cockroach infestation and standards of hygiene [13]. Various studies have revealed that cockroaches aggregate in corners in kitchens, especially around the refrigerators and in the bathrooms around chests, around plumbing connections within or between rooms and/or flats $[1,14,15]$. As cockroaches are engaged in their nocturnal forages, they drop off shed skins, nymphal shed skins and fecal pellets.

Most of the Gram positive bacteria isolated from the cuticle were coagulase negative staphylococci [16]. It is possible that the antimicrobial agents that are present in the secretions produced by the male accessory glands may have a role in selecting against certain types of bacteria [17]. Cockroaches are possible vectors of pathogenic bacteria in hospital environments $[18,19,20]$. Up to $54 \%$ of isolates from hospital environments were found to be human pathogens [21].

More than $33.3 \%$ of cockroach isolates were resistant to more than three antimicrobials (some to 6 or more) [16]. Resistance covered a large diversity of microbes including Salmonella, [22] enterobacteria and coagulase negative staphylococci [23].

There has been great concern about cockroaches carrying and spreading microorganisms as they forage in the houses, and at the same time on to foodstuffs and 
working areas in the kitchen, which could result in allergic reactions from consumers $[24,25]$. The current study was carried out to determine population ranges of cockroaches in three localities around Gaborone, the external microbial load and diversity of cockroaches, the microbial diversity of the fecal pellets and the antibiotic resistance of the bacterial isolates.

\section{MATERIALS AND METHODS}

\section{Sampling sites, sample sizes and sampling method}

Three housing sampling localities in Gaborone, Tlokweng, Old Naledi and those occupied by the University of Botswana (UB) staff in the Gaborone Central, Broadhurst, Village and Gaborone West sub districts, were selected for the purpose. The three groups also represent different income groups with the UB staff earning much higher than Tlokweng, and Old Naledi the least. Since the houses occupied by the University staff were more broadly distributed, with a more extensive spread, 50 different households were sampled collectively from Gaborone Central/Broadhurst/Village/Gaborone West. Only ten houses were sampled from each of the two smaller localities; namely Old Naledi and Tlokweng. This represents the 90 $\%$ households from where samples were collected. Cockroaches were trapped using Dyroach sticky traps (Roberts, South Africa).

\section{Bacteriological analysis}

In order to determine surface-adhering bacteria, 10-40 German cockroaches were randomly picked from each trap using forceps and transferred into sterile dilution bottles containing peptone water following aseptic techniques. This was then shaken vigorously by hand before appropriate aliquots were transferred into diluents. Further dilutions were made as deemed necessary.

Nutrient agar was used for enumerating aerobic mesophilic bacteria; spore formers were cultivated on nutrient agar and enumerated after samples were heat treated for 8 $10 \mathrm{~min}$ at $80^{\circ} \mathrm{C}$. Total coliforms, fecal (thermostable) coliforms and E. coli were estimated by MPN values as described previously [26, 27]. Escherichia coli isolates were further characterized using API 20E (BioMerieux, France). Salmonella and Shigella isolates were pre-enriched as previously described [28]. Bacillus cereus was grown on Bacillus cereus agar for confirmation of lecithinase and characteristic colony coloration. Listeria monocytogenes was grown on Listeria isolation medium [29]. The remaining bacterial isolates picked from nutrient agar plates including the pathogens were purified on appropriate media and inoculated into BIOLOG supplied microplates for phenotypic finger printing (BIOLOG, Hayward, California, USA) and API 20E strips for Enterobacteriaceae.

\section{Fecal pellets}

Fecal pellets were diluted in peptone water. Appropriate aliquots from serial dilutions were plated onto nutrient agar (Oxoid, Basingstoke, UK), S-S agar (Oxoid, Basingstoke, UK), Bacillus cereus agar (Oxoid, Basingstoke, UK) and Listeria 


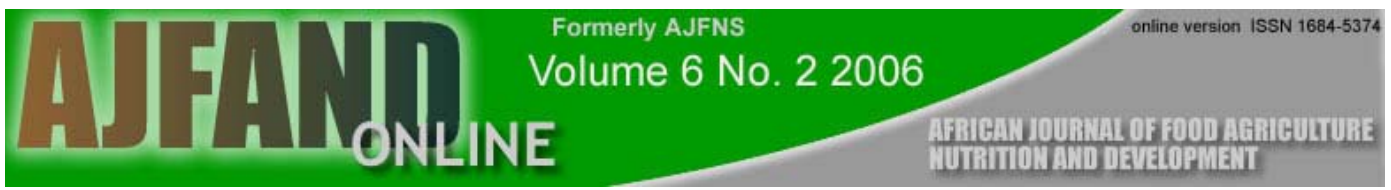

isolation medium (Oxoid, Basingstoke, UK). The temperature of incubation was 35-37 ${ }^{\circ} \mathrm{C}$.

\section{Antibiotic sensitivities}

The Bauer-Kirby procedure was performed on the identified isolates using the following antibiotic discs: for Gram positives- chloramphenicol, $25 \mu \mathrm{g}$; erythromycin, 5 $\mu \mathrm{g}$; fusidic acid, $10 \mu \mathrm{g}$; methicillin, $10 \mu \mathrm{g}$; novobiocin, $5 \mu \mathrm{g}$; penicillin $\mathrm{G}, 1$ unit; streptomycin, $10 \mu \mathrm{g}$; tetracycline, $10 \mu \mathrm{g}$; vancomycin, $30 \mu \mathrm{g}$; cefepime, $30 \mu \mathrm{g}$; cefprozil, $30 \mu \mathrm{g}$ and for Gram negatives - ampicillin, $10 \mu \mathrm{g}$; cephalothin, $5 \mu \mathrm{g}$; colistin sulfate, $25 \mu \mathrm{g}$; gentamycin, $10 \mu \mathrm{g}$; streptomycin, $10 \mu \mathrm{g}$; tetracycline, $25 \mu \mathrm{g}$; sulphatriad, $200 \mu \mathrm{g}$; cefepime, $30 \mu \mathrm{g}$; cefprozil, $30 \mu \mathrm{g}$; and cotrimoxazole, $25 \mu \mathrm{g}$. Inhibition diameters were measured and interpreted according to manufacturer's recommendations (Mast Diagnostics, UK) [30].

\section{RESULTS}

Aerobic mesophilic, total spore and coliform counts from the surface of cockroaches The bacterial population found on the surface of the cockroaches varied according to household, where in the household it was trapped and the localities where it was trapped, as shown in Tables 1, 2 and 3. As many as $67 \%, 22.2 \%$ and $28.6 \%$ of the cockroaches trapped from the kitchens in the Central/Broadhurst area, Old Naledi and Tlokweng localities had bacterial counts of $\geq 10^{6} \mathrm{CFU} /$ cockroach, respectively. The population of cockroaches with bacterial population of $\geq 10^{6} \mathrm{CFU} /$ cockroach trapped from the toilets, however, were higher than those from the kitchens in Old Naledi and Tlokweng (35.2\% and $33.4 \%$ ), respectively. But the percentages were lower from cockroaches trapped in the Central/Broadhurst area (45\%) as seen in Tables 1, 2 and 3.

Spore bearing bacteria were found in $86.7 \%, 45.4 \%$ and $76.1 \%$ of the samples of cockroaches trapped in kitchens from Central/Broadhurst, Old Naledi and Tlokweng localities, respectively. On the other hand, spore formers were isolated from $54.4 \%$, $5.9 \%$ and $45 \%$ of the cockroach samples trapped from the toilets in Central/Broadhurst, Old Naledi and Tlokweng localities, respectively.

Bacillus cereus, the food poisoning bacteria, was only found in $14 \%, 3.7 \%$ and $4.8 \%$ of the samples collected from the kitchens at Central/Broadhurst, Old Naledi and Tlokweng, respectively. Bacillus cereus was also found in $22.6 \%$ of the samples of cockroaches from the toilets in Central/Broadhurst locality. Bacillus cereus was not found on cockroaches collected from the toilets at Old Naledi and Tlokweng localities.

Coliforms were present in 70-98.3\% of cockroach samples that were trapped from both the kitchens and toilets at the three localities. Over $90 \%$ of the samples trapped from the kitchens in Central/Broadhurst locality had coliforms in the range of $10^{2}$ to $10^{5}$ CFU/cockroach, whereas the range was represented by only $74 \%$ and $71.4 \%$ of the cockroach samples from Old Naledi and Tlokweng, respectively. On the other hand, $90.3 \%, 76.5 \%$ and $65 \%$ of the toilet samples at Central/Broadhurst, Old Naledi and Tlokweng, respectively, had coliforms within that range. 
The presence of fecal coliforms did not correlate with the presence of E. coli on the cockroaches. Escherichia coli was found in $21.6 \%, 33.3 \%$ and $23.8 \%$ of the samples collected from the kitchens at Central/Broadhurst, Old Naledi and Tlokweng localities, respectively. However, E. coli was found in $19.5 \%, 35.3 \%$, and $30 \%$ of the samples trapped from the toilet at Central/Broadhurst, Old Naledi and Tlokweng, respectively. Escherichia coli was only found in $5-6.5 \%$ of samples at population of $\geq 10^{3}$ /cockroach in the three localities.

\section{Spectrum of bacterial isolates from surface and fecal pellet of cockroaches}

70 species of bacteria belonging to 37 genera were isolated from cockroaches-from the surface and fecal pellets (Table 4). Most of the bacterial isolates from the fecal pellets were 'Gram positive' and often spore formers. The exception to this was the presence of E. coli and other members of the family Enterobacteriaceae which is expected. On the other hand, the most predominant isolates from the surface were Pseudomonas spp. and Serratia spp., followed by members of Enterobacteriaceae.

\section{Susceptibility of bacterial isolates to antimicrobials}

There was single to multiple resistance to antibiotics by the isolates. Each of the four 'Gram positive' and 'Gram negative' isolates which have been randomly selected for presentation appear in Table 5. Resistance to $\beta$-lactam antibiotics (penicillin and cephalothin) was wide spread amongst the Gram positive and Gram negative isolates (data not shown). In addition, the Gram negatives were also resistant to the membrane disrupting agent, colistin sulfate and the folic acid inhibitors, sulphatriad and cotrimoxazole. Resistance to vancomycin, streptomycin and cefprozil was common among the Brevibacterium species; however, other isolates were susceptible to these antibiotics. Gram positives were generally susceptible to chloramphenicol, erythromycin and fusidic acid.

\section{DISCUSSION}

A previous survey of surface bacterial loads of cockroaches trapped in residences of students, teachers and low income employees had revealed average total counts of 1.35 $\times 10^{8}, 5.99 \times 10^{7}$ and $1.64 \times 10^{8}$ respectively [8]. The values presented here (Tables 1 , $2,3)$ approach that of the counts for cockroaches trapped from the residence of teachers but are lower by a factor 1-2 when compared to cockroaches trapped from student and low income employees residences [8]. The percentages of cockroaches carrying bacterial load of $\geq 10^{6} \mathrm{CFU} /$ cockroach was much smaller in the toilet than the kitchen at Central/Broadhurst. This might indicate the cleanliness of the toilets in these neighborhoods. It might also suggest the use of disinfectants for cleaning toilets since the population in this group can afford to buy disinfectants. At the other two localities where the toilets are mostly detached latrines (sometimes pits), and where cockroaches might have easy access to human excrements, there was no significant difference in bacterial load of the cockroaches either from the kitchens or toilets. 
Spore formers make up a significant population of soil bacteria around Gaborone [26]. This was not the case in the sample of cockroaches studied. We expected to find spore formers making up a significant portion of the population on the surface of cockroaches. But, the population of the spore formers was very low on most cockroaches. There was also an apparent difference between cockroaches carrying spore formers in the kitchens and toilets within the localities. It was surprising to find that $B$. cereus was present on cockroaches at all localities in the kitchens. Its absence from cockroaches trapped in the toilets of the other two localities (Naledi, and Tlokweng) could not be justified.

Thermally stable coliforms made up a significant portion of the total coliforms at households in all localities. This is a good indication that cockroaches come in contact with the soil bacteria Klebsiella, Enterobacter and Citrobacter species.

Some of the bacterial isolates are known to be pathogenic (Salmonella, Shigella, B. cereus) while others are either opportunistic pathogens (Pseudomonas, Klebsiella, Vibrio) or play roles in food spoilage (Pseudomonas, Enterobacter, Escherichia, Erwinia). Species belonging to these groups of bacteria have also been confirmed to be cockroach-borne previously [31,32].

Many studies have also revealed the predominance (up to $88 \%$ ) of isolates of Gram negative bacteria on the cuticle of cockroaches. Most of them belong to the group Enterobacteriaceae [8, 16, 32]. In fact, Blattaria are considered to be an ecological niche of some Enterobacteriaceae [6]. When Gram positive bacteria were present on the surface, their population was very low, or totally absent. This is perplexing, since Gram negatives dominate on the surface of cockroaches and Gram positives in the fecal pellets (Tables 1, 2, 3, 4). Why this kind of association might exist needs further enquiry. It might demonstrate the presence of a selective pressure on the bacteria as a result of bioactive compound(s) produced by the cockroach. The low numbers of spore formers on the surfaces but higher numbers in the fecal pellets could suggest such kind of selective mechanism produced by the cockroach and requires further investigation [17].

The resistance of the isolates to some antibiotics was surprising since antibiotics are not normally applied on cockroaches. The mode of actions of the disinfectants in use at the household level could not be a selective factor for any of the antibiotic resistance displayed in the current study. Antibiotic resistance of organisms associated with foods has been reported [28]. It is probable that the close association of cockroaches with food is responsible for the resistance of organisms isolated from cockroaches. This, again, requires thorough investigation concerning micro-organisms associated with cockroaches. 


\section{CONCLUSION}

Cockroaches carry micro-organisms on their surfaces and fecal pellets. They carry food borne pathogens and food spoilage organisms wherever they crawl or forage in the home. Their presence in homes compromises the best practices in food safety and quality. The bacteria carried by the cockroaches display multiple antibiotic resistance. Therefore, utmost effort must be taken to drive cockroaches out or by controlling their population at the household level. Being aware of the potential for carrying pathogens, people at the household level should strive to keep their kitchens and toilets clean and prevent cockroach infestation.

\section{ACKNOWLEDGEMENTS}

This project was made possible through the generous funding by the University of Botswana Research and Publications Committee and the Southern African Consortium of Universities for Development and the Environment (SACUDE), DANIDA project, at the University of Botswana. The research team is grateful for this funding. We acknowledge the assistance received from the technical staff in the Department of Biological Sciences, in particular Mr. Isaac Morobe. We are grateful to the colleagues at the University of Botswana who assisted in the trapping of cockroaches in their homes. 


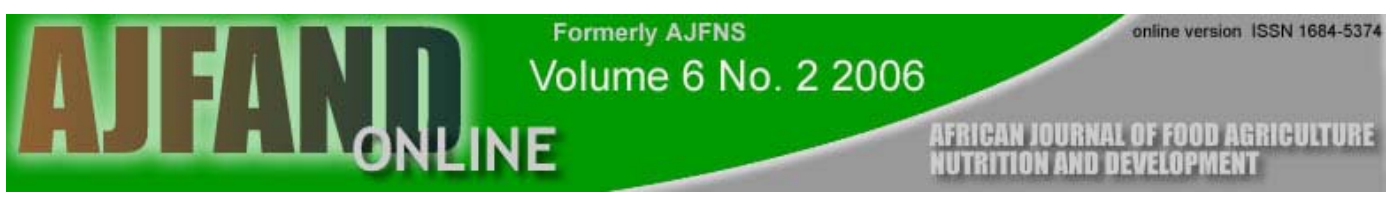

Table 1: Bacterial population ranges, total spores, total coliforms, fecal coliforms and E. coli from the surface of cockroaches trapped from the kitchen and toilet in Central/Broadhurst locality

\section{Bacterial range $\left(\log _{10}\right)$}

\begin{tabular}{|c|c|c|c|c|c|c|c|c|}
\hline Sample $^{1}$ & $1-2$ & $2-3$ & 3-4 & $4-5$ & $5-6$ & $6-7$ & $7-8$ & $8-9$ \\
\hline \multicolumn{9}{|l|}{ Kitchen } \\
\hline $\mathrm{Spc}$ & - & - & 3.6 & 7.3 & 21.8 & 45.5 & 16.4 & 5.5 \\
\hline TS & 52.8 & 22.6 & 9.4 & 1.9 & - & - & - & - \\
\hline $\mathrm{Bc}$ & 12 & 2 & - & - & - & - & - & - \\
\hline $\mathrm{TC}$ & 3.8 & 35.8 & 32.1 & 26.6 & - & - & - & - \\
\hline $\mathrm{FC}$ & 39.2 & 35.3 & 15.7 & 3.9 & - & - & - & - \\
\hline Ec & 11.8 & 9.8 & - & - & - & - & - & - \\
\hline
\end{tabular}

Toilet

$\begin{array}{lllllllll}\text { SPC } & - & - & 9.6 & 9.6 & 35.4 & 35.4 & 3.2 & 6.4 \\ \text { TS } & 32.1 & 2.9 & 9.7 & 6.5 & 3.2 & - & - & - \\ \text { Bc } & 12.9 & 9.7 & - & - & - & - & - & - \\ \text { TC } & - & 3.2 & 61.3 & 22.6 & 3.2 & - & - & - \\ \text { FC } & 6.5 & 16.1 & 32.3 & 9.7 & - & - & - & - \\ \text { Ec } & 6.5 & 6.5 & 6.5 & - & - & - & - & -\end{array}$

Iabbreviations: spc, standard plate count; TS, total spore count; Bc, Bacillus cereus count; TC, total coliforms; FC, fecal coliforms; Ec, Escherichia coli. 


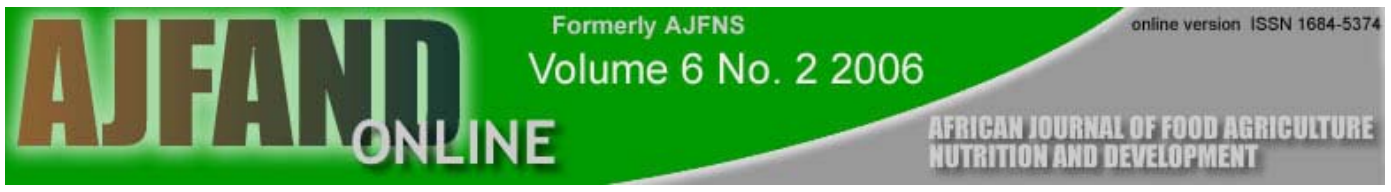

Table 2: Bacterial population ranges, total spores, total coliforms, fecal coliforms and E. coli from the surface of cockroaches trapped from the kitchen and toilet in Old Naledi locality

\section{Bacterial range $\left(\log _{10}\right)$}

\begin{tabular}{|c|c|c|c|c|c|c|c|}
\hline Sample $^{1}$ & $1-2$ & $2-3$ & $3-4$ & $4-5$ & $5-6$ & $6-7$ & $7-8$ \\
\hline \multicolumn{8}{|l|}{ Kitchen } \\
\hline SPC & - & 3.7 & 14.8 & 29.6 & 29.6 & 7.4 & 14.8 \\
\hline $\mathrm{TS}$ & 11.1 & 22.2 & 7.4 & 3.7 & - & - & - \\
\hline $\mathrm{Bc}$ & 3.7 & - & - & - & - & - & - \\
\hline $\mathrm{TC}$ & 7.4 & 11.1 & 48.1 & 14.8 & - & - & - \\
\hline $\mathrm{FC}$ & 14.8 & 11.1 & 18.5 & 14.8 & - & - & - \\
\hline $\mathrm{Ec}$ & 18.5 & 7.4 & 7.4 & - & - & - & - \\
\hline \multicolumn{8}{|l|}{ Toilet } \\
\hline SPC & - & - & 23.5 & 23.5 & 17.6 & 17.6 & 17.6 \\
\hline $\mathrm{TS}$ & 5.9 & - & - & - & - & - & - \\
\hline $\mathrm{Bc}$ & - & - & - & - & - & - & - \\
\hline $\mathrm{TC}$ & 5.9 & 29.4 & 35.3 & 11.8 & - & - & - \\
\hline $\mathrm{FC}$ & 29.4 & 17.6 & 5.9 & 5.9 & - & - & - \\
\hline $\mathrm{Ec}$ & 23.5 & 5.9 & 5.9 & - & - & - & - \\
\hline
\end{tabular}

labbreviations: spc, standard plate count; TS, total spore count; Bc, Bacillus cereus count; TC, total coliforms; FC, fecal coliforms; Ec, Escherichia coli. 


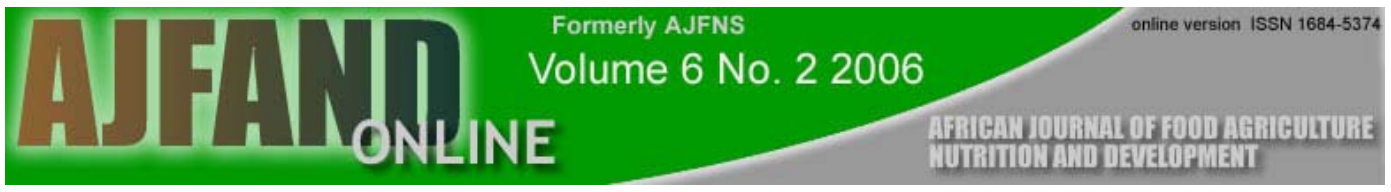

Table 3: Bacterial population ranges, total spores, total coliforms, fecal coliforms and E. coli from the surface of cockroaches trapped from the kitchen and toilet in Tlokweng locality

\section{Bacterial range $\left(\log _{10}\right)$}

$\begin{array}{lllllllll}\text { sample } & \mathbf{1 - 2} & \mathbf{2 - 3} & \mathbf{3 - 4} & \mathbf{4 - 5} & \mathbf{5 - 6} & \mathbf{6 - 7} & \mathbf{7 - 8} & \mathbf{8 - 9} \\ -\mathrm{Nitchen} & & & & & & & & \\ \text { SPC } & - & 14.3 & 14.3 & 23.8 & 19 & 14.3 & 14.3 & - \\ \text { TS } & 42.9 & 23.6 & 4.8 & 4.8 & - & - & - & - \\ \text { Bc } & 4.8 & - & - & - & - & - & - & - \\ \text { TC } & 19 & 28.6 & 33.3 & 9.5 & - & - & - & - \\ \text { FC } & 14.3 & 14.3 & 9.5 & 4.8 & - & - & - & - \\ \text { Ec } & 19 & 4.8 & - & - & - & - & - & -\end{array}$

Toilet

\begin{tabular}{lllllllll} 
SPC & - & 16.7 & 5.6 & 11.1 & 33.3 & 16.7 & 16.7 & - \\
TS & 35 & 10 & - & - & - & - & - & - \\
Bc & - & - & - & - & - & - & - & - \\
TC & 5 & 20 & 35 & 10 & - & - & - & - \\
FC & 10 & 20 & 15 & 10 & - & - & - & - \\
Ec & 25 & - & - & 5 & - & - & - & - \\
\hline
\end{tabular}

' abbreviations: spc, standard plate count; TS, total spore count; Bc, Bacillus cereus count; TC, total coliforms; FC, fecal coliforms; Ec, Escherichia coli. 


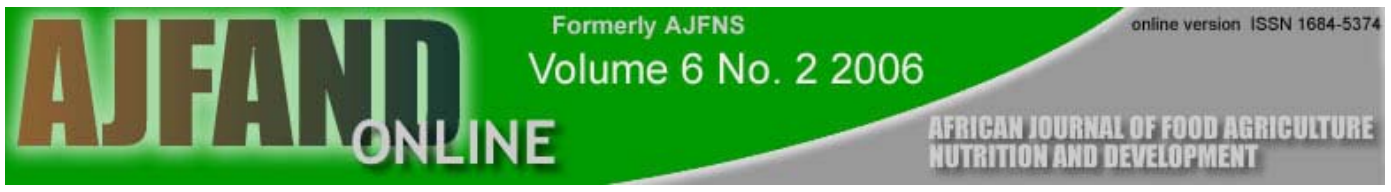

Table 4: Bacterial diversity on the surface and fecal pellets of cockroaches

\section{Name of isolate}

Actinomyces randingae

Alcaligenes faecalis

Arthrobacter cumminnsii

Aureubacterium spp. (2) ${ }^{4}$

Bacillus spp. (11)

Brevibacterium spp. (5)

Burkholderia vietnamiensis

Buttiauxella sp

CDC Group II E Subgroup A

Citrobacter sp.

Corynebacterium spp. 4)

Enterobacter spp.

Erwinia sp.

Escherichia coli

Hafnia sp

Kigali sp.

Klebsiella spp.

Kluyvera sp.

Kauri rosea

Leuconostoc sp.

Micro bacterium spp.

Micrococcus sp.

Proteus spp. (2)

Providence ruttier

Pseudomonas spp. (5)

Rhodococcus australis

Rhodococcus rhodochrous

Salmonella typhimurium

Serratia spp. (4)

Shigella sp.

Spingobacterium thalpophilum

Staphylococcus spp. (4)

Stenotrophomonas maltophillia

Streptococcus sp.

Tsukamurella inchonensis

Vibrio metschnikovii

Xanthomonas spp. (3)

\section{cockroach}

$\underline{\text { Fecal pellet }} \underline{\text { surface }}$

$+$

$+$

$+$

$+$

$+$

$+$

$+$

$+$

$+$

$+$

$+$

$+$

$+$

$+$

$+$

$+$

$+$

$+$

$+$

$+$

$+$

$+$

$+$

$+$

$-$

$+$

$+$

$-$

$+$

$+$

$+$

${ }^{4}$ Numbers in parenthesis indicate species identified.

(-) absent; (+) present.

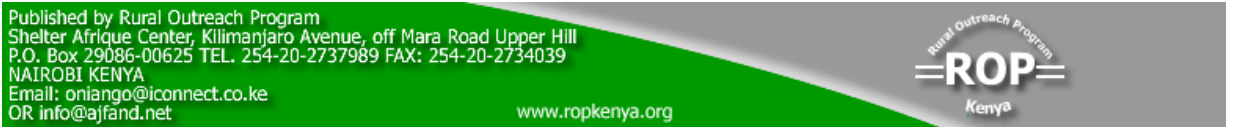




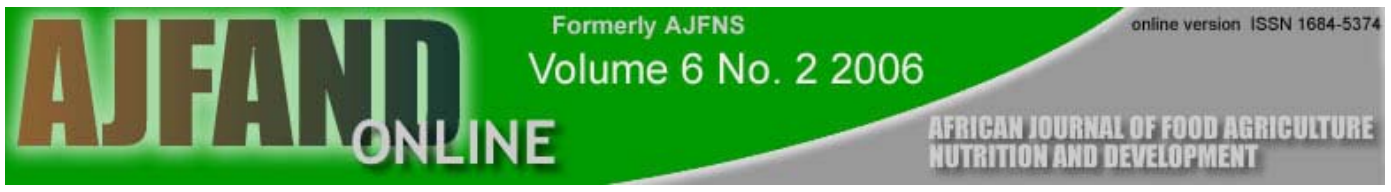

Table 5: Antibiotic sensitivity of selected bacteria from cockroaches

\begin{tabular}{|c|c|c|c|c|}
\hline \multirow[b]{2}{*}{ Antibiotic* } & \multirow[b]{2}{*}{ B. cereus } & \multicolumn{3}{|c|}{ Gram positive bacterial isolates } \\
\hline & & $\begin{array}{l}\text { Brevibacterium } \\
\text { epidermis }\end{array}$ & $\begin{array}{l}\text { Coryne- } \\
\text { bacterium sp. }\end{array}$ & $\begin{array}{l}\text { Staphylococcus } \\
\text { scheiferi }\end{array}$ \\
\hline PG & + & + & + & + \\
\hline Str & + & + & + & + \\
\hline $\mathrm{T}$ & - & + & + & + \\
\hline $\mathrm{V}$ & - & + & + & + \\
\hline $\mathrm{Ce}$ & + & + & + & - \\
\hline $\mathrm{Cp}$ & - & + & + & + \\
\hline A & + & + & + & + \\
\hline $\mathrm{C}$ & - & + & + & + \\
\hline $\mathrm{E}$ & - & + & + & + \\
\hline $\mathrm{F}$ & + & + & + & + \\
\hline M & + & + & + & + \\
\hline \multirow[t]{3}{*}{$\mathrm{N}$} & + & + & + & + \\
\hline & & \multicolumn{2}{|c|}{ Gram negative bacterial isolates } & \\
\hline & E. coli & $\begin{array}{ll}\text { Proteus } & P s \\
\text { mirabilis } & a e\end{array}$ & $\begin{array}{l}\text { omonas } \\
\text { nosa }\end{array}$ & $\begin{array}{l}\text { Vibrio } \\
\text { metschnekovii }\end{array}$ \\
\hline $\mathrm{Cph}$ & + & + & + & + \\
\hline Co & - & + & - & + \\
\hline $\mathrm{G}$ & + & + & - & - \\
\hline Sul & + & + & - & + \\
\hline Cot & + & + & + & + \\
\hline Sty & + & - & - & - \\
\hline $\mathrm{T}$ & + & - & - & + \\
\hline Cep & + & + & - & + \\
\hline $\mathrm{Cp}$ & + & + & + & + \\
\hline A & + & + & + & + \\
\hline $\mathrm{Ce}$ & + & - & - & - \\
\hline
\end{tabular}

$(+)$, represents resistance and (-) sensitivity to antibiotic.

*PG, penicillin G; Str, streptomycin; T, tetracycline; V, vancomycin; Ce, cefepime; Cph, cephalothin; A, ampicillin; C, chloramphenicol; E, erythromycin; F, fusidic acid; M, methicillin; N, novobiocin; Co, colistin sulfate; G, gentamycin; Sul, sulphatriade; Cep, cefprozil; Cot, cotrimoxazole. 


\section{REFERENCES}

1 Tanaka I and M Motoki Release and Recapture of German Cockroaches Blattella germanica (L) in a Vacant House. In: KB Wildey and WH Robinson (Eds) Proc. $1^{\text {st }}$ Int. Conf. on Insects Pests in the Urban Env., Cambridge, UK, 1993: 281-283.

2 Boase CJ Trends in Urban Refuse Disposal. In: Wm H Robinson, F Rettich and GW Rambo (Eds) Proc. $3^{\text {rd }}$ Int. Conf. on Insects Pests in the Urban Env., Prague, Czech Rep., 1999: 83-98.

3 Oteng M Insects as Vectors of Pathogenic Microorganisms in Street Vended Foods. BSc Project. Department of Biological Sciences, University of Botswana, 2003.

4 Rivault C, Cloarec A and A LeGuyader Cockroaches as Vectors of Pathogenic Bacteria in Urban Environments. Ecologie. 1994; 25: 103-109.

5 Adler C, Navarro S, Choler M, Stengard-Hansen L, Reppchen A, Prezel S. and A Beckmann Integration of Chemical Control of Cockroaches and Biological Control of Stored-Product Moths. Bulletin OIL/SROP. 2002; 25: $21-$ 25.

6 Pellegrini G, Levre E., Valentini P. and M Cadoni Cockroach Infestation and possible Contribution to the Spread of some Enterobacteria. Igiene Moderna 1992; 97: 19-30.

$7 \quad$ Bennet G Cockroaches as Carriers of Bacteria. Lancet (British Ed). 1993; 341: 732.

8 Paul S, Khan AM, Baqui MA and M Muhibullah Evaluation of the Common Cockroach Periplaneta americana (L) as Carrier of Medically Important Bacteria. Journal of Communicable Diseases 1992; 24: 206-210.

9 Onuegbu BA Dispersal of Viable Conidia of Onion Black Mould (Aspergillus niger) by the Cockroach (Periplaneta americana). Onion Newsletter for the Tropics 1994; 6: 63-64.

10 Fotedar $\mathbf{R}$ and $\mathbf{U}$ Banerjee Nosocomial Fungal Infections: Study of the possible Role of Cockroaches (Blattella germanica) as Vectors. Acta Tropica 1992; 50: 339-343.

11 Marty AM Cockroaches can Vector human Diseases. Int. J. Dermatology 1998; 37: 639-640. 
12 Branscone D Disease-transmitting Pests. Pest Control Tech. 2002; 30: 82-84.

13 Shah VJ, Learmont $\mathbf{J}$ and $\mathbf{D}$ Pinniger Infestations of German Cockroach Blattella germanica in Multi-Occupancy Dwellings in a London Borough-A Preliminary Study into the Relationship between Environment, Infestation and Control Success. In: KB Wildey (Ed) Proc. $2^{\text {nd }}$ Int. Conf. on Insects Pests in the Urban Env., Edinburgh, Scotland, 1996: 203-209.

14 Rivault G, Cloarec A and A LeGuyader Bacterial Load of Cockroaches in Relation to Urban Environment. Epidemiology and Infection 1993a; 110: $317-$ 325 .

15 Bennett G, Runstrom $\mathbf{E}$ and $\mathbf{J}$ Bertholf Examing the Where, Why and How of Cockroach Control. Pest Control 1984; 52:42, 43, 46, 48.

16 Sramova H, Daniel M, Absolonova V, Dedicova D, Jedlickova Z, Urotova $\mathbf{H}$, Petras P and V Subertova Epidemiological Role of Arthropods detectable in Health Facilities. J. of Hospital Infect. 1992; 20: 281-292.

17 Gilliot C Male Accessory Gland Secretions: Modulators of Female Reproductive Physiology and Behaviour. Annu. Rev. Ent. 2003; 48: 163-184.

18 Kim kitae, Jeon JinHwa and Lee DongKyu Various Pathogenic Bacteria on German Cockroaches (Blattellidae: Blattaria) Collected from General Hospitals. Korean J. Ent. 1995; 25: 85-88.

19 Cotton MF, Wasserman E, Pieper CH, Theron DC, Tubbergh D van, Campbell G, Fang FC and $\mathbf{G}$ Barnes Invasive Disease due to Extended Spectrum Beta-Lactamase-Producing Klebsiella pneumoniae in a Neonatal Unit: the possible Role of Cockroaches. J. Hospt. Infect., 2000; 44: 13-17.

20 Gliniewicz A, Czajka E, Laudy AE, Kochman M, Crzegorzak K, Ziolkowska, K, Sawicka B, Stypulkowska-Misiurewicz H and JA Hopskins 2003. German cockroaches (Blattella germanica L) as a potential source of pathogens causing nosocomial infections. Indoor and Built Environment 12 $(1 / 2): 55-60$.

21 Devi SJN and CJ Murray Cockroaches (Blatta and Periplaneta spp.) as Reservoirs of Drug Resistant Salmonellae. Epidemiology and Infection 1991; 107: $35-361$.

22 Kopani RJ Jr, Sheldon BW and CG Wright Cockroaches as Vectors of Salmonella: Laboratory and Field Trials. J. Food Prot.1994; 57:125-132. 
23 Prado MA, Pimenta FC, Hayashid M, Souza PR, Pereira MS and E Gir Enterobacteria Isolated from Cockroaches (Periplaneta americana) Captured in a Brazilian Hospital. Pan Americana J. Public Health 2002; 11: 93-98.

24 Cloarec A, Rivault G, Fontaine F and A LeGuyader Cockroaches as Carriers of Bacteria in Multifamily Dwellings. Epidemiology and Infection 1992; 109: 483-490.

25 Brenner RJ Implications of Cockroach Behavior, Allergens and Pathogenic Associates to the Food Supply and Human Health. Proc. $3^{\text {rd }}$ World Congress on Food borne Infect. and Intoxication 1992; 2:1111-1114.

26 Mpuchane S and BA Gashe Prevalence of Coliforms in Traditionally Dried Leafy Vegetables Sold in Open Markets and Food Stores in Gaborone, Botswana. J. Food Prot. 1997; 59: 28-30.

27 Mpuchane S, Gashe BA, Allotey J, Siame B, Teferra G and M Ditlhogo Quality Deterioration of Phane, the Edible Caterpillar of an Emperor Moth Imbrasia belina. Food Control 2000; 11: 453-458.

28 Gashe BA and S Mpuchane Prevalence of Salmonella on Beef Products at Butcheries and their Antibiotic Resistance Profiles. J. Food Science 2000 64: 880-883.

29 Collins CH, Lyne PM and JM Grange Collins and Lyne's Microbiological Methods, $7^{\text {th }}$ ed. Butterworth and Heinmann: London, 1995.

30 Bauer AW, Kirby WMM, Sherris JC and M Turk Antibiotic Susceptibility Testing by a Standard Single Disc Diffusion Method. Amer. J. Clinical Pathol. 1966; 45: 493-496.

31 Jay JM Modern Food Microbiology, $4^{\text {th }}$ Edition. Chapman and Hall: New York, 1992.

32 Rivault G, Cloarec A and A LeGuyader 1993b. Bacterial Contamination of Food by Cockroaches. J. Env. Health 1993b; 55: 21-22. 